\title{
Article \\ Identification of Distant Regulatory Elements Using Expression Quantitative Trait Loci Mapping for Heat-Responsive Genes in Oysters
}

\author{
Kexin Zhang $1,2,3,+$, Jinpeng Wang ${ }^{1,2,3,4,+}$, Fangfang Ding ${ }^{1,2,3}$, Ruihui Shi ${ }^{1,2,3} \mathbb{D}$, Wei Wang ${ }^{1,5,6}$, \\ Guofan Zhang ${ }^{1,2,6}$ and $\mathrm{Li} \mathrm{Li}{ }^{1,3,5,6, *}$
}

1 CAS and Shandong Province Key Laboratory of Experimental Marine Biology, Center for Ocean Mega-Science, Institute of Oceanology, Chinese Academy of Sciences, Qingdao 266071, China; 17854203920@163.com (K.Z.); wangjinpeng0225@163.com (J.W.); qd_dingfangfang@163.com (F.D.); shiruihui123@163.com (R.S.); wangwei@qdio.ac.cn (W.W.); gfzhang@ms.qdio.ac.cn (G.Z.)

2 Laboratory for Marine Biology and Biotechnology, Pilot National Laboratory for Marine Science and Technology, Qingdao 266237, China

3 University of Chinese Academy of Sciences, Beijing 100049, China

4 Institute of Animal Science and Veterinary Medicine, Shandong Academy of Agricultural Sciences, Jinan 250100, China

5 Laboratory for Marine Fisheries Science and Food Production Processes, Pilot National Laboratory for Marine Science and Technology, Qingdao 266237, China

6 National and Local Joint Engineering Laboratory of Ecological Mariculture, Qingdao 266071, China

* Correspondence: lili@qdio.ac.cn; Tel.: +86-0532-8289-6728

check for

updates

Citation: Zhang, K.; Wang, J.; Ding, F.; Shi, R.; Wang, W.; Zhang, G.; Li, L. Identification of Distant Regulatory Elements Using Expression Quantitative Trait Loci Mapping for Heat-Responsive Genes in Oysters. Genes 2021, 12, 1040. https: / / doi.org/ 10.3390 /genes 12071040

Academic Editor: Manuel Vera Rodríguez

Received: 30 May 2021

Accepted: 28 June 2021

Published: 5 July 2021

Publisher's Note: MDPI stays neutral with regard to jurisdictional claims in published maps and institutional affiliations.

Copyright: (c) 2021 by the authors. Licensee MDPI, Basel, Switzerland. This article is an open access article distributed under the terms and conditions of the Creative Commons Attribution (CC BY) license (https:// creativecommons.org/licenses/by/ $4.0 /)$.
+ These authors contributed equally to this work.

\begin{abstract}
Many marine ectotherms, especially those inhabiting highly variable intertidal zones, develop high phenotypic plasticity in response to rapid climate change by modulating gene expression levels. Herein, we examined the regulatory architecture of heat-responsive gene expression plasticity in oysters using expression quantitative trait loci (eQTL) analysis. Using a backcross family of Crassostrea gigas and its sister species Crassostrea angulata under acute stress, 56 distant regulatory regions accounting for $6-26.6 \%$ of the gene expression variation were identified for 19 heat-responsive genes. In total, 831 genes and 164 single nucleotide polymorphisms (SNPs) that could potentially regulate expression of the target genes were screened in the eQTL region. The association between three SNPs and the corresponding target genes was verified in an independent family. Specifically, Marker13973 was identified for heat shock protein (HSP) family A member 9 (HspA9). Ribosomal protein L10a (RPL10A) was detected approximately $2 \mathrm{~kb}$ downstream of the distant regulatory SNP. Further, Marker14346-48 and Marker14346-85 were in complete linkage disequilibrium and identified for autophagy-related gene 7 (ATG7). Nuclear respiratory factor 1 (NRF1) was detected approximately $3 \mathrm{~kb}$ upstream of the two SNPs. These results suggested regulatory relationships between RPL10A and HSPA9 and between NRF1 and ATG7. Our findings indicate that distant regulatory mutations play an important role in the regulation of gene expression plasticity by altering upstream regulatory factors in response to heat stress. The identified eQTLs provide candidate biomarkers for predicting the persistence of oysters under future climate change scenarios.
\end{abstract}

Keywords: oyster; thermal adaption; heat-responsive gene; expression quantitative trait loci (eQTL) mapping; distant regulatory locus

\section{Introduction}

Climate change has resulted in rapid global ocean warming [1], which threatens the survival and performance of marine ectotherms [2]. Studies suggest that phenotypic plasticity, the ability to exhibit several different phenotypes with the same genotype [3], plays an important role in species' responses to global warming [4-7]. Oysters have 
high phenotypic plasticity, which at morphological and molecular levels allow them to adapt to highly variable intertidal zones. This ability makes them ideal representatives of intertidal organisms for the study of adaptive mechanisms in response to heat and other environmental stresses [8-10]. Gene expression variation accounts for much of the phenotypic variation among populations and individuals in response to rapid climate change [11-14].

Energy balance and cellular homeostasis are fundamental for survival and adaption to environmental stress [15]. Transcriptomic and proteomic analyses reveal changes in genes and proteins that are involved in cellular homeostasis, protein stability, metabolic adjustment, signaling transduction, and ion transportation and so on under heat stress in marine organisms. Heat shock proteins (HSP)s and genes related to metabolic adjustment and ion transport show differential expression in fish exposed to elevated temperatures $[16,17]$. In shrimp, HSPs are strongly upregulated under heat stress $[18,19]$. Genes related to protein homeostasis, oxidative stress mediation, osmolyte transport, and apoptosis are expressed differentially under different temperatures in shellfish [10,20-25]. Elucidating the genetic basis of heat-responsive gene expression will reveal the underlying mechanisms of phenotypic plasticity and lead to a better understanding of thermal adaption to global warming.

Expression quantitative trait locus (eQTL) mapping, which locates genetic loci related to mRNA transcript abundance in a segregation population [26,27], can link genetic variants to gene expression and phenotypes [11]. eQTLs are genomic regions containing several genetic variants that can influence gene expression [11] and are classified into local and distant eQTLs according to their distance from the target gene [28]. Most local eQTLs regulate gene expression through cis-acting regulation, which directly influences target gene expression and protein characteristics (cis-eQTLs). Distant eQTLs are usually transacting [11], and can change target gene expression by influencing the function, structure, and expression of other factors (trans-eQTLs). However, distant cis and local trans effects have also been reported [28]. Genome-wide eQTL mapping for the detection of genetic loci linked to phenotypes has been used for many species [29] to elucidate the underlying mechanisms of complex traits [30-35]. Aquatic ectotherms, the most susceptible groups in response to the deterioration of the environment, are ideal organisms to study to unravel the underlying mechanisms of high plasticity in gene expression. However, the detection of genetic variants of environment-responsive gene expression by eQTL mapping in marine ectotherms has only been studied thus far in three-spined stickleback [36].

Oysters have high economic value and are top ranking in global mariculture but unfortunately suffer summer mortality [37-39] mainly due to high temperatures [40]. Therefore, understanding the mechanism of high thermal adaption in oysters will elucidate prediction of marine organisms' adaptive potential to global warming and help tackle oyster summer mortality. Moreover, oysters have high fecundity, which facilitates eQTL analysis. The Pacific oyster, C. gigas, and its sister species, C. angulata, are distributed along the northern and southern coasts of China, respectively [41]. The two species can interbreed, and both exhibit thermal tolerance divergence at physiological and molecular levels [8]. The basic and plastic expression of heat-responsive genes is differentiated between the two species [10].

This study aimed to elucidate the genetic variants regulating heat-responsive gene expression under acute heat stress by eQTL mapping. We identified several eQTLs using a previously reported high-density genetic map [42]. We further validated the association between the single nucleotide polymorphisms (SNPs) located in the eQTLs and the expression of the corresponding heat-responsive genes in an independent family. To our knowledge, this is the first study to identify the potential regulatory locus of environmentally responsive genes by integrating differential gene expression into QTL mapping in mollusks. Our results will help to highlight the adaptive mechanisms of marine organisms in response to environmental stress and provide a potential target region of genetic modification in the selection for thermal resistance in oysters. 


\section{Materials and Methods}

\subsection{Origin and Background of Oysters}

Two backcross families of $C$. gigas and $C$. angulata were used in this study. ZF2-3 included 106 individuals and was used for eQTL mapping. ZF was used for subsequent association analysis between genotypes and gene expression levels. The two families were produced in a hatchery in Qingdao, China $\left(36^{\circ} 12^{\prime} \mathrm{N}, 120^{\circ} 41^{\prime} \mathrm{E}\right)$ in 2012 . Both the male parents of the two backcross families were the progeny of the hybrid family of $C$. gigas and C. angulata, which were produced and cultured in Nan'ao Island, Shantou, China ( $23^{\circ} 25^{\prime} \mathrm{N}$, $117^{\circ} 01^{\prime} \mathrm{E}$ ). Both the female parents were 2-year-old wild C. gigas from Jiaonan, Qingdao, China $\left(35^{\circ} 44^{\prime} \mathrm{N}, 119^{\circ} 56^{\prime} \mathrm{E}\right)$. The procedure to construct the families were described in the previous study [42]. Briefly, both the parent oysters were dissected manually, the gonads of male parents were rinsed in seawater for activation of sperm for $30 \mathrm{~min}$, and the gonads of female parents were rinsed in seawater for activation of egg for $1 \mathrm{~h}$. Few sperm add to eggs for fertilization (no more than 10 sperm around one egg). The oyster larval were reared in a $70 \mathrm{~L}$ tank for 1 month until they attached to the settlement substrate. And then they were reared in a marine farm in Qingdao.

\subsection{Heat Stress Simulation}

Before the heat stress simulation, the progeny was collected at 14 months-old from the marine farm and transferred to the indoor laboratory, where they were reared in natural seawater and feed with culture algae for two weeks. For the acute heat stress treatment, seawater was heated and maintained at $35^{\circ} \mathrm{C}$ using an automatic temperature controller connecting with a heating rod (ZHONGKEHAI, China), Both the progeny of ZF2-3 and $\mathrm{ZF}$ families was placed into the seawater at $35^{\circ} \mathrm{C}$ for $3 \mathrm{~h}$. Air was pumped into the water throughout the entire experiment.

\subsection{DNA and RNA Extraction}

Gills and mantles were sampled from each heat-treated oyster, immediately frozen in liquid nitrogen, and stored at $-80^{\circ} \mathrm{C}$ for RNA and DNA extraction, respectively. Approximately $20 \mathrm{mg}$ of gill tissue was used for total RNA extraction, according to RNAprep pure Tissue Kit (TIANGEN, Beijing, China) instructions. Total DNA was extracted using a TIANamp Marine Animals DNA Kit from approximately $30 \mathrm{mg}$ of mantle tissue. The DNA and RNA concentrations were measured using a NanoDrop 2000 spectrophotometer (Thermo Fisher Scientific, Waltham, MA, USA). Sample quality was identified using 1.0\% agarose gel electrophoresis.

\subsection{Genotyping-by-Sequencing}

For ZF2-3 family, we used the same SNP dataset produced by genotyping-by- sequencing as described in Wang et al. [42]. Briefly, the EcoRI-HinfI combination was selected for digesting the genomic DNA; the digested DNA fragments were ligated to adaptors with barcodes; barcoded DNAs of parents and progenies of ZF2-3 family were mixed together and separated on a $2 \%$ agarose gel; DNA fragments of 400-600 bp (including adaptor) were selected and purified; the selected DNA fragments were amplified by PCR; PCR products were purified with Agencourt AMPure XP beads (Beckman Coulter, High Wycombe, UK); purified DNA fragments were sequenced on IlluminaHiseq 2500 platform (Illumina, San Diego, CA, USA). The Stacks software was used to analyze the sequencing data and to genotype DNA variations in the mapping family. The Pacific oyster reference genome oyster_v9 (GenBank accession no. GCA_000297895.1) was applied for SNP calling [25].

\subsection{Detection of Thermal Responsive Gene Expressions}

Twenty-one previously-reported thermal responsive candidate genes [10,24,25], were selected for quantitative real-time PCR. Gene IDs and primers are shown in Table 1. All primer design was conducted with Primer Premier 5. Elongation factor $1 \alpha(E F 1 \alpha)$ was used as the reference gene. One microgram of RNA from each sample was used for cDNA 
synthesis with the Evo M-MLV RT Kit II (AG, China). The synthetic cDNA was diluted 20 times for subsequent RT-PCR. The reaction system was: $2 \mu \mathrm{L}$ cDNA, $10 \mu \mathrm{L}$ SYBR Green 2X Supermix (TaKaRa Bio Inc., Shiga, Japan), $6.8 \mu \mathrm{L} \mathrm{DEPC} \mathrm{H}_{2} \mathrm{O}, 0.4 \mu \mathrm{L}$ sense and anti-sense primer, and $0.4 \mu \mathrm{L}$ ROX Dye II. The reaction program was as follows: $30 \mathrm{~s}$ at $95{ }^{\circ} \mathrm{C}, 5 \mathrm{~s}$ at $95^{\circ} \mathrm{C}$ for 40 cycles, and $30 \mathrm{~s}$ at $60^{\circ} \mathrm{C}$. The melt curve program was as follows: $15 \mathrm{~s}$ at $95^{\circ} \mathrm{C}$, $1 \mathrm{~min}$ at $60{ }^{\circ} \mathrm{C}, 30 \mathrm{~s}$ at $95^{\circ} \mathrm{C}$, and $15 \mathrm{~s}$ at $60^{\circ} \mathrm{C}$. RT-PCR was conducted using the ABI7500 Fast Real-Time Detection System (Applied Biosystems, Foster City, CA, USA). Relative gene expression was determined using the $2^{-\Delta \Delta \mathrm{Ct}}$ method $[10,43]$.

Table 1. Heat responsive Gene ID and primer, F represent sense primer, R represent anti-sense primer.

\begin{tabular}{|c|c|c|}
\hline Gene Name & Gene ID & Primer Sequence $\left(5^{\prime}-3^{\prime}\right)$ \\
\hline \multirow[b]{2}{*}{ HSPA4 } & \multirow{2}{*}{ CGI_10017255 } & F:ACCAAGCACAACTCTGAAT \\
\hline & & R:AGGCTGAGTATCCACAATG \\
\hline \multirow{2}{*}{ HSPA5-08834 } & \multirow{2}{*}{ CGI_10008834 } & F:CCAGAACGACAACAACAGACTCTCA \\
\hline & & R:TTGGCTTCAACCTTCTCCTTCACTT \\
\hline \multirow{2}{*}{ HSPA12A } & \multirow{2}{*}{ CGI_10002491 } & F:CCACGTCATCAGGTCGATACAGAGA \\
\hline & & R:GCAATATGCTGTCTACGGCTGGTT \\
\hline \multirow{2}{*}{ HSPA12B-22078 } & \multirow{2}{*}{ CGI_10022078 } & F:CTCTCACTGCGGACAAACTTCGT \\
\hline & & R:GCTTTCCACTTCTGGGTGCTGTAA \\
\hline \multirow{2}{*}{ PARP4 } & \multirow{2}{*}{ CGI_10013249 } & F:ATAGCCAGGGTTGGAGCAGGTT \\
\hline & & R:ACGGATACCGAGGTCAGCACTG \\
\hline \multirow{2}{*}{ HYOU1 } & \multirow{2}{*}{ CGI_10027129 } & F:CTAACGGACGAGGACCACGAGAA \\
\hline & & R:ACCTCCTTCTTGGCATCCTCTTCC \\
\hline \multirow{2}{*}{ HSPA13 } & \multirow{2}{*}{ CGI_10027222 } & F:TCCATACCAAGCCTGAGCTGAAGA \\
\hline & & R:TACACGGAGTAGCGACACATCCA \\
\hline \multirow{2}{*}{ HSPA12B-12492 } & \multirow{2}{*}{ CGI_10012492 } & F:CTGAAGATCCAGGACTTGCTGTGTT \\
\hline & & R:GCCAGCTCTGAATGCCATAAGTGT \\
\hline \multirow{2}{*}{ HSPA9 } & \multirow{2}{*}{ CGI_10016162 } & F:TCACTCCGCTGTCGTTGGGTAT \\
\hline & & R:TGTCCATCAGCAGCCGTTGAGA \\
\hline \multirow{2}{*}{ HSPA5-15492 } & \multirow{2}{*}{ CGI_10015492 } & F:ACCGTGGAGTCAACCCTGATGA \\
\hline & & R:CGTCCAACAGCAGAAGGTCACC \\
\hline \multirow{2}{*}{ HSP68 } & \multirow{2}{*}{ CGI_10002594 } & F:TCAGCCAAGGACAAGAGCACAG \\
\hline & & R:TCGGCCTCGTTCACCATTCTCT \\
\hline \multirow{2}{*}{ SIP1 } & \multirow{2}{*}{ CGI_10004164 } & F:CGCCATTACGGACGGCAAGAA \\
\hline & & R:ACGGTAATGTGGTCAGGCTCGA \\
\hline \multirow{2}{*}{ HSPB1 } & \multirow{2}{*}{ CGI_10017582 } & F:CCGAAGGAAGAGGACCAGGAGATG \\
\hline & & R:CGAACACCGACAGGTCTAAACTCTC \\
\hline DIB13 & & F:CACATTTCCAGAAGAAGGCGACCA \\
\hline DJD13 & CGl_100069/7 & R:GAACCTTGGCAGTGTGGATCAGATT \\
\hline DNIB4 & CGI 10009495 & F:GGAGGAGACGACCCGTTTGCTA \\
\hline & & R:GTTGCCCGCCGAAATGGAACA \\
\hline & & F:CCTGGTTACATTGGTGATTTCC \\
\hline CLCN2 & CG1_10022926 & R:CTCAGCCTGTCCTGTCGTC \\
\hline BRKS2 & CGI 10010977 & F:TGGATAGTCACGGATTAGTAGAG \\
\hline BKKSL & CGl_10010977 & R:GGGGTTCCTGAGTTTTCG \\
\hline MTMR8 & CGI 10006555 & F:TGTTTGTTCCTGCCTCCG \\
\hline МНМाК & CG1_10000350 & R:CCTTTACCAGCCGCCTTA \\
\hline & & F:CACTGGACACCCCTGAAC \\
\hline ATG7 & CGI_10025698 & R:GCAACAAAGAAACCCTGAT \\
\hline & CGI 10028689 & F:CGACAAAGGACAGTGCGAGTA \\
\hline GAK & CG1_10020089 & R:CTGAATGGCTGACCAAGACC \\
\hline & & F:TCCGTCATCTCCCACTCC \\
\hline RNF123 & CGl_10004/87 & R:TTCTTTGTCСТTTCTTCССТ \\
\hline
\end{tabular}

\section{6. eQTL Analysis}

The aforementioned relative gene expression was used as the phenotype for eQTL mapping, and genotype data were acquired from a high-density SNP genetic linkage map constructed by the aforementioned backcross family [42]. The construction process was described in detail by Wang et al. [42]. QTL mapping analysis was conducted to 
detect eQTLs for corresponding gene expression regulation using MapQTL6 [44], interval mapping (IM), and restricted multiple QTL model mapping (rMQM). An IM model was used for the selection of cofactors. eQTLs were acquired using rMQM with multiple selections of cofactors. A permutation test was conducted 3000 times at $p<0.05$ to determine the significant LOD threshold. eQTLs with LOD scores exceeding the chromosome-wide LOD threshold were considered significantly related to gene expression. Candidate genes were screened within a $100 \mathrm{~kb}$ region around these significant SNP markers in eQTL regions. Enrichment and classification analysis of Gene Ontology (GO) [45] and Kyoto Encyclopedia of Genes and Genomes (KEGG) pathways [46] were performed with R. Fisher's exact test was used for the GO enrichment analysis. GO enrichment results were ranked by $p$-value and the top 20 were selected to visualize the results.

\subsection{Verification of eQTLs for an Independent Family}

The relationship between each marker genotype and expression of the corresponding gene was investigated using the Mann-Whitney test, and the threshold for a significant difference was set at 0.05 .

\subsubsection{Genotyping by SNaPshot}

SNPs in the eQTL regions that had no mutations at $30 \mathrm{bp}$ upstream and downstream were selected for association analysis. Genotyping was conducted using SNaPshot (3730xL $\times$ L DNA Applied Biosystems) in the ZF hybrid groups. Peripheral amplification primers and unidirectional oligonucleotide primers of different lengths were designed for these mutations (Table S1). After the multiplex reaction, the PCR product was separated by electrophoresis with five-color fluorescence detection and analyzed using Gene Mapper 4.1. Multiple SNP sites were detected simultaneously.

\subsubsection{Statistical Analysis}

Allele frequency and genotype frequency were calculated using SHesis (http:// analysis.bio-x.cn/myAnalysis.php, accessed on 11 August 2020) [47-49]. Since our data didn't meet the normal distribution and homogeneity of variance, non-parametric test is adopted in our analysis. Specially, Mann-Whitney test was used for the analysis of variance in gene expression levels among different genotypes with two genotypes. For three genotypes, Kruskal-Wallis test was used. All analyses were performed using GraphPad Prism software. $p<0.05$ was considered statistically significant.

\section{Results}

\subsection{Gene Expression Analysis}

The gene expression data are shown in Supplementary Table S2. The gene expression exhibited large phenotypic fold changes (8-642) and the distribution was positively skewed (Supplementary Figure S1). Phenotypic variation was rich, and the variable coefficient of each gene expression level was greater than 0.5 .

\section{2. eQTL Mapping and Distant eQTLs for Candidate Gene Expression}

A total of 56 significant eQTLs were mapped for 19 of the 21 genes, covering 164 SNPs. The phenotypic variation explanation (PVE) ranged from $6 \%$ to $26.6 \%$. eQTL details and mapping results are shown in Table 2 and Supplementary Figure S2, respectively. All the investigated genes and their related eQTLs (distant) were located on different scaffolds. Most SNPs affected the expression of only one target gene, whereas 29 SNPs affected two target genes. Three important SNPs affected the expression of more than two heatresponsive genes. Marker7064 was located in eQTL regions of three target genes: HSPA12A, HSPA13 and HSPA12B-12492. Four genes (HSPA12A, HYOU1, HSPA13 and HSPA12B-12492) colocalized with the same regulatory SNP: Marker25714. Marker13973 also was detected for GAK, HSPA4, HSPA9, and HSPB1. 
Table 2. Summary of candidate expression quantitative trait loci (eQTL) regions of 19 genes by eQTL mapping. eQTL names, linkage groups, confidence intervals (CIs), nearest markers, peak of LODs, number of markers, and phenotypic variation explanation (PVE) are shown in the table.

\begin{tabular}{|c|c|c|c|c|c|c|c|}
\hline Gene ID & eQTL Name & $\begin{array}{l}\text { Linkage } \\
\text { Group }\end{array}$ & CI (cM) & $\begin{array}{l}\text { Nearest } \\
\text { Marker }\end{array}$ & Peak LOD & $\begin{array}{l}\text { Number of } \\
\text { Markers }\end{array}$ & PVE (\%) \\
\hline \multirow[t]{3}{*}{ HSPA4 } & eqtl_HSPA4_7 & 7 & $59.305-59.559$ & Marker13973 & 5.73 & 1 & 11.4 \\
\hline & eqtl_08834_1 & 1 & $37.775-38.056$ & Marker10740 & 6.85 & 3 & 11 \\
\hline & eqtl_08834_2 & 2 & $55.886-56.171$ & Marker27538 & 6.8 & 3 & 12.2 \\
\hline \multirow[t]{3}{*}{ HSPA5-08834 } & eqtl_08834_3 & 3 & $70.226-70.319$ & Marker7956 & 7.55 & 1 & 13.7 \\
\hline & eqtl_08834_6 & 6 & $45.588-47.109$ & Marker10629 & 4.25 & 3 & 6 \\
\hline & eqtl_08834_10 & 10 & 55.184-63.734 & Marker8139 & 3.97 & 14 & 6.6 \\
\hline \multirow[b]{2}{*}{ HSPA12A } & eqtl_HSPA12A_2 & 2 & $76.025-76.531$ & Marker18003 & 6.55 & 2 & 12.5 \\
\hline & eqtl_HSPA12A_6 & 6 & $85.9-86.9$ & Marker25714 & 7.12 & 2 & 13.4 \\
\hline \multirow{2}{*}{ HSPA12B-22078 } & eqtl_22078_2 & 2 & 75.66 & Marker2650 & 8.52 & 1 & 17.1 \\
\hline & eqtl_22078_6 & 6 & 86.854 & Marker25714 & 9.29 & 1 & 19 \\
\hline \multirow[t]{2}{*}{ HYOU1 } & eqtl_HYOU1_8 & 8 & $70.508-71.201$ & Marker27468 & 7.19 & 4 & 17.2 \\
\hline & eqtl_HSPA13_2 & 2 & 75.66 & Marker2650 & 6.89 & 1 & 15.2 \\
\hline \multirow{4}{*}{ HSPA13 } & eqt1_HSPA13_6-1 & 6 & $85.852-86.854$ & Marker28123 & 9.56 & 5 & 21.9 \\
\hline & eqtl_HSPA13_6-2 & 6 & $93.738-97.367$ & Marker36658 & 6.9 & 5 & 16.5 \\
\hline & eqtl_HSPA13_6-3 & 6 & $80.218-80.894$ & Marker36719 & 6.27 & 2 & 15.3 \\
\hline & eqtl_12492_4 & 4 & $67.045-68.122$ & Marker1504 & 7.07 & 1 & 9.7 \\
\hline \multirow[t]{3}{*}{ HSPA12B-12492 } & eqtl_12492_5 & 5 & 29.69-31.306 & Marker4421 & 6.31 & 3 & 10.1 \\
\hline & eqtl_12492_6 & 6 & $86.284-86.854$ & Marker25714 & 8.24 & 3 & 13.8 \\
\hline & eqtl_HSPA9_2 & 2 & $56.171-56.918$ & Marker32411 & 5.87 & 3 & 10.8 \\
\hline \multirow[t]{4}{*}{ HSPA9 } & eqtl_HSPA9_3 & 3 & 58.831 & Marker37157 & 11.39 & 2 & 24.9 \\
\hline & eqtl_HSPA9_7 & 7 & $59.305-59.559$ & Marker13973 & 8.02 & 1 & 16.2 \\
\hline & eqtl_15492_3-1 & 3 & $55.568-62.396$ & Marker37157 & 5.68 & 17 & 14.8 \\
\hline & eqtl_15492_3-2 & 3 & $70.226-70.319$ & Marker7956 & 7.61 & 1 & 19.1 \\
\hline \multirow[t]{3}{*}{ HSPA5-15492 } & eqtl_15492_4 & 4 & $25.851-26.48$ & Marker20355 & 4.43 & 3 & 9.6 \\
\hline & eqtl_15492_5 & 5 & $66.47-71.853$ & Marker45911 & 4.82 & 4 & 11.2 \\
\hline & eqtl_15492_6 & 6 & $47.913-54.293$ & Marker37730 & 4.11 & 5 & 8.2 \\
\hline SIP1 & eqtl_SIP1_3 & 3 & 68.861-68.966 & Marker34975 & 12.71 & 1 & 26.6 \\
\hline \multirow{4}{*}{ HSPB1 } & eqtl_HSPB1_1 & 1 & 13.509 & Marker30594 & 6.14 & 1 & 10.6 \\
\hline & eqtl_HSPB1_7 & 7 & 59.305-59.559 & Marker13973 & 5.1 & 1 & 8.6 \\
\hline & eqtl_DJB13_4-1 & 4 & 77.435-77.904 & Marker5101 & 7.41 & 2 & 13.4 \\
\hline & eqtl_DJB13_4-2 & 4 & $81.469-81.772$ & Marker30102 & 7.41 & 2 & 14.8 \\
\hline \multirow{4}{*}{ DJB13 } & eqtl_DJB13_9-1 & 9 & $31.72-31.793$ & Marker23397 & 7.77 & 2 & 15.6 \\
\hline & eqtl_DJB13_9-2 & 9 & 26.511-30.02 & Marker32635 & 5.93 & 14 & 12.4 \\
\hline & eqtl_DJB13_9-3 & 9 & $40.641-41.260$ & Marker6180 & 4.7 & 5 & 10.1 \\
\hline & eqtl_DJB13_9-4 & 9 & $22.587-23.134$ & Marker13132 & 4.53 & 3 & 9.8 \\
\hline \multirow{3}{*}{ DNJB4 } & eqtl_DNJB4_3 & 3 & 68.966 & Marker34975 & 6.55 & 1 & 12.4 \\
\hline & eqtl_DNJB4_5 & 5 & 70.735 & Marker38934 & 6.03 & 1 & 11.3 \\
\hline & eqtl_ATG7_4 & 4 & $12.875-15$ & Marker12663 & 8.32 & 5 & 8.9 \\
\hline \multirow{3}{*}{ ATG7 } & eqtl_ATG7_5 & 5 & $80.077-84.62$ & Marker14346 & 12.74 & 6 & 15.3 \\
\hline & eqtl_ATG7_6 & 6 & $74.921-76.921$ & Marker26545 & 10.47 & 1 & 11.9 \\
\hline & eqtl_ATG7_10 & 10 & 82.583-85.39 & Marker17442 & 8.78 & 2 & 9.3 \\
\hline \multirow{2}{*}{$B R K S 2$} & eqtl_BRKS2_3 & 3 & 67.861-68.966 & Marker34975 & 8.2 & 1 & 17.2 \\
\hline & eqtl_BRKS2_8 & 8 & $50.382-50.764$ & Marker35461 & 7.87 & 2 & 16.4 \\
\hline \multirow[b]{2}{*}{ CLCN2 } & eqtl_CLCN2_8 & 8 & 101.355-101.509 & Marker20478 & 6.17 & 1 & 15.4 \\
\hline & eqtl_CLCN2_9 & 9 & 46.8-47.215 & Marker16655 & 5.84 & 3 & 14.7 \\
\hline$G A K$ & eqtl_GAK_7 & 7 & 59.305-59.559 & Marker13973 & 6.37 & 1 & 12 \\
\hline \multirow{2}{*}{ MTMR8 } & eqtl_MTMR8_5 & 5 & $30.419-33.214$ & Marker43580 & 6.92 & 6 & 12.7 \\
\hline & eqtl_MTMR8_9 & 9 & $45.837-48.737$ & Marker30815 & 6.4 & 6 & 15.9 \\
\hline \multirow{8}{*}{ RNF123 } & eqtl_RNF123_5-1 & 5 & 73.043 & Marker3732 & 9.01 & 1 & 19.7 \\
\hline & eqtl_RNF123_5-2 & 5 & $67.803-72.526$ & Marker49357 & 6.61 & 11 & 15.2 \\
\hline & eqtl_RNF123_9-1 & 9 & $0-3$ & Marker8801 & 10.71 & 1 & 20.7 \\
\hline & eqtl_RNF123_9-2 & 9 & $4-5.149$ & Marker7204 & 8.35 & 2 & 15.2 \\
\hline & eqtl_RNF123_9-3 & 9 & $8.219-8.229$ & Marker31542 & 6.84 & 2 & 14.6 \\
\hline & eqtl_RNF123_9-4 & 9 & $10.631-12.125$ & Marker44034 & 7.15 & 6 & 15.1 \\
\hline & eqtl_RNF123_9-5 & 9 & $13.521-13.73$ & Marker8825 & 6.16 & 4 & 13.4 \\
\hline & eqtl_RNF123_9-6 & 9 & $20.193-20.556$ & Marker43279 & 5.89 & 3 & 12.8 \\
\hline
\end{tabular}

A total of 831 candidate genes around these 164 SNPs are shown in supplementary Table S3. These genes were enriched in 93 KEGG pathways that mainly participated in metabolism, genetic information processing, environmental information processing, cellular processes, and human diseases (Figure S3). Functional enrichment analysis suggested that candidate genes were mainly involved in protein heterodimerization activity, DNA 
binding, nucleosome assembly, and centrosome duplication (Figure S4). Furthermore, 10 transcription factors were detected in the eQTLs of five target genes (HSPA5-08834, HYOU1, HSPA13, ATG7, RNF123).

\subsection{Verification of Distant eQTLs in Different Families}

Eleven critical distant regulatory SNPs located in nine distant regulatory regions for seven genes were genotyped and tested for associations with the expression of the corresponding genes in family ZF; Marker28123 and Marker30775 for HSPA13, Marker12828 and Marker11127 for HSPA5-15492, Marker13973 for HSPA4, HSPA9, and HSPB1, Marker61915 for HSPA9, Marker35461 for BRKS2, Marker20478 for CLCN2, Marker1434648 and Marker14346-85 for ATG7, and Marker10740 for HSPA5-08834. Only six distantacting loci (Marker 28123, Marker13973, Marker35461, Marker20478, Marker14346-48, and Marker14346-85) for seven genes were found to be polymorphic in the verification family. The genotype and allele frequencies of these six SNPs are shown in Supplementary Table S4.

The association between Marker13973 and the expression level of HSPA9 was significant $(p<0.05)$ using the Mann-Whitney test $(p=0.0395, n=85$, Figure 1a, Table S5). Gene expression analysis indicated that individuals with the CG genotype had higher expression levels. Both Marker14346-85 and Marker14346-48 were significantly associated with the expression level of ATG7 ( $p<0.0001, n=78$, Figure 1b,c, Table S5). Individuals with CT at Marker14346-85 and TC at Marker14346-48 showed higher ATG7 expression levels. Marker14346-85 and Marker14346-48 were $36 \mathrm{bp}$ apart and in complete linkage disequilibrium $\left(\mathrm{D}^{\prime}=1\right)$. Three haplotypes were identified: CT, CC, and TT $(p<0.05$, Table S6).

a.

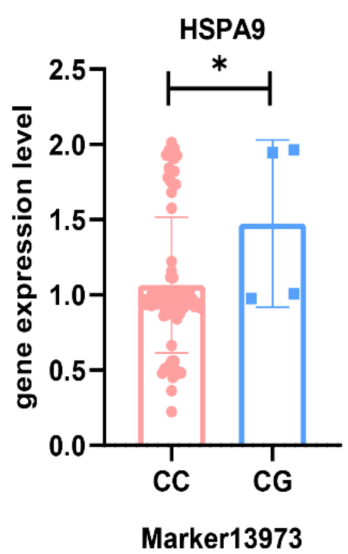

b.

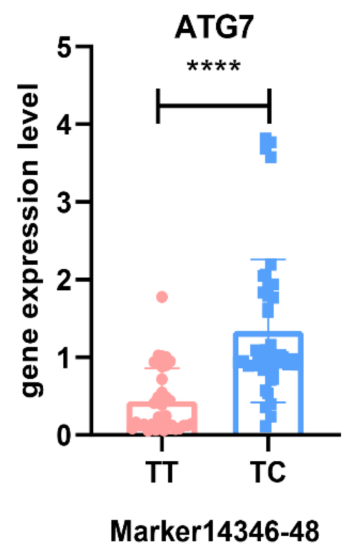

c.

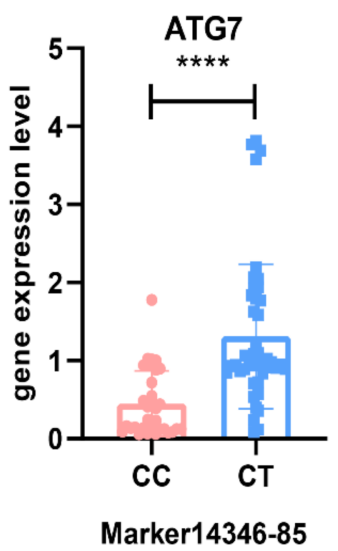

Figure 1. Association between different genotypes of single nucleotide polymorphisms (SNPs) and the gene expression level. (a) HSPA9 gene expression level with different genotypes of Marker13973. (b) ATG7 gene expression level with different genotypes of Marker14346-48. (c) ATG7 gene expression level with different genotypes of Marker14346-85. The error bars denote the standard error of the mean. Asterisks indicate significant differences between different genotypes of SNPs. * indicates $p<0.05 .{ }^{* * * *}$ indicates $p<0.0001$.

\section{Discussion}

Herein, we detected 56 distant eQTLs, including 164 SNPs, without a local regulatory locus. The phenotypic variation of single regulatory loci at the transcript level was generally higher $(6-26.6 \%)$ than growth-related traits $(0.6-13.8 \%)$ using the same genetic map in Pacific oysters [42], which may due to the complexity of growth-related traits. However, the PVE in our study was generally lower than $8.4-59.7 \%$ of the tuber starch content relative genes at the transcript level in potatoes [50]. Also, a major local regulatory locus could 
even explain 70\% of the muscle IGF2 expression variance in pigs [51]. The limitation of the number and density of markers in the linkage map may explain why we did not detect any major local-eQTL in our study.

This study contains all distant changes and no local changes, which corroborate other studies' findings of more distant than local changes [31,33,52,53]. A gene can be regulated by many distant mutation loci, but only a few local loci, which may be the reason why a higher proportion of distant eQTL has been reported [54]. Many studies considered that local eQTLs played a stronger and more significant role in regulatory ability than distant eQTLs because of their local activity $[55,56]$. However, recent studies have also realized the importance of distant eQTLs [31,57,58], which account for the majority of heritability in human gene expression and participate in gene-environment interactions [11]. Furthermore, one distant eQTL in a hotspot region may influence many genes by working in gene networks.

We also found three distant regulatory SNPs linked with three or four heat-responsive genes, which may be located in potential distant eQTL hotspot regions. Regulators such as transcription factors, nuclear receptors, miRNAs and small nuclear RNAs usually cluster near distant eQTL hotspot regions [31]. We found one regulatory element in our potential distant eQTL hotspot regions, RPL10A.

In this study, candidate genes within distant regulatory regions were enriched in pathways of environmental and genetic information processing. Other studies have illuminated that distant eQTLs can cause the functional divergence of several components that transduce environmental signals into gene expression changes [59]. Our results further complement the viewpoint that distant regulatory loci might influence the expression or function of regulatory elements that respond to environmental changes. In addition to linkage analysis, the associations between one distant regulatory SNP and HSPA9 and between two distant regulatory SNPs and ATG7 were further verified in an independent population, implying that these SNPs are important distant regulatory loci. The distant regulatory SNPs could affect the expression and function of target genes by mediating other regulatory factors. ATG (autophagy-related) proteins are the core of the autophagic machinery. ATG7 encodes an E1-like activating enzyme and facilitates autophagic vesicle expansion by working with microtubule-associated protein light chain 3 (LC3) and ATG12 [60,61]. In the distant eQTL regions of $A T G 7$, one transcription factor, nuclear respiratory factor 1 (NRF1) was detected $3 \mathrm{~kb}$ upstream from the two distant regulatory SNPs (Figure 2a). NRF1 encodes a transcription factor that activates the expression of metabolic genes involved in cellular growth and development [61]. In combination with the finding that NRF1 can upregulate the expression level of ATG7 by binding to its promoter in humans [62], we propose that the two distant regulatory SNPs (Marker14346-48 and Marker14346-85) might regulate the expression level of ATG7 by affecting the expression of NRF1. The eQTLs and the validated SNPs provide candidate regions and markers to predict the adaptive potential in response to climate change. HSPAs are ubiquitous molecular chaperones that participate in many biological processes [63-65]. In the distant eQTL regions of HSPAs, we found RPL10A, a highly conserved gene with a variable number of spliceosomal introns in most organisms [66], approximately $2 \mathrm{~kb}$ downstream from the regulatory SNP of HSPA9 (Figure 2b). We suggest that this distant regulatory locus Marker13973 might influence the expression of HSPA9 by regulating the synthesis of RPL10A. The regulatory relationship between RPL10A and HSPA9 was already elaborated in white shrimp [67].

Our results demonstrate the importance of distant eQTLs in adaptive evolution and elucidate the underlying regulatory mechanism of thermal adaption. The three regulatory SNPs identified might be used as potential regulatory loci of thermal adaption and could be applied to genetic improvements of heat-resistant oysters. However, we did not confirm the regulatory relationship among SNPs, gene expression, and high temperature resistance traits, which could be topics of further study. 

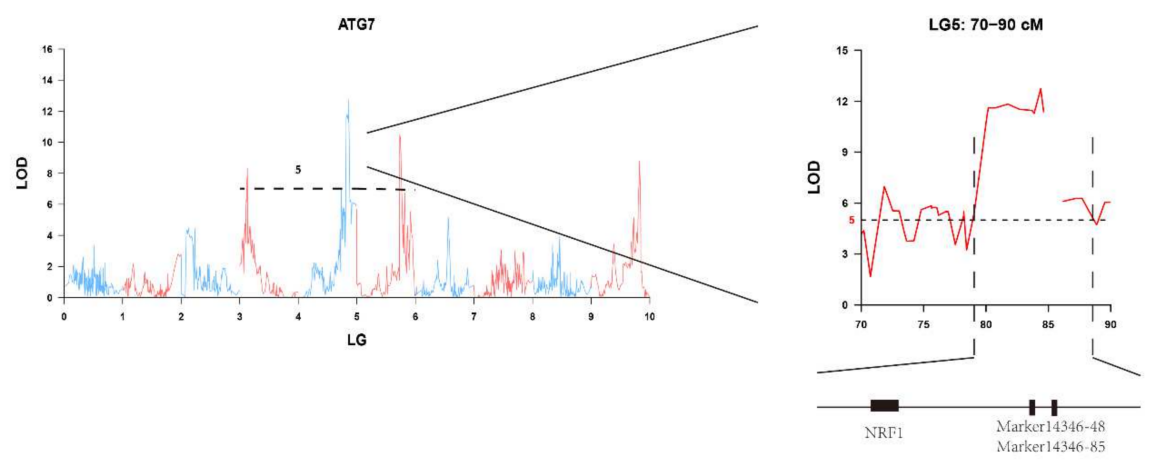

b.
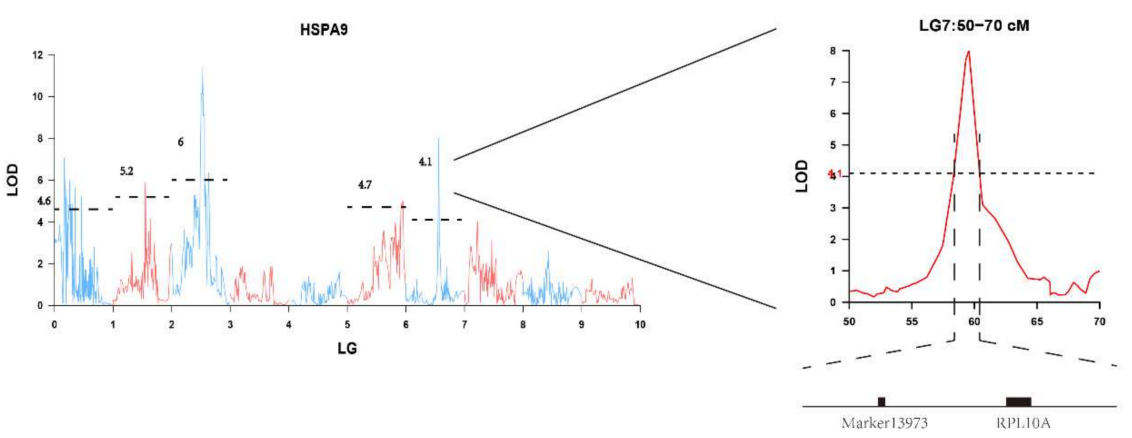

Figure 2. Plots of expression quantitative trait loci (eQTL) mapping and candidate regulatory loci and genes HSPA9 and ATG7. (a) eQTL mapping of HSPA9. (b) eQTL mapping of ATG7. The black horizontal dashed line on each plot represents the chromosome-wide threshold of significance. Black rectangles represent candidate genes. Black vertical lines represent the regulatory single nucleotide polymorphism (SNP).

Supplementary Materials: The following are available online at https: / www.mdpi.com/article/ 10.3390/genes12071040/s1, Table S1: Peripheral amplification primers and unidirectional oligonucleotide primers of SNPs, Table S2: Gene expression level of 21 heat-responsive genes in 106 individuals, Figure S1: Histogram of heat-responsive gene expression distribution in the mapping family, Figure S2: Plots of eQTL mapping of 21 heat-responsive genes, Table S3: Candidate genes identified from eQTL mapping of C. gigas, Figure S3: Classification analysis of KEGG pathway of 831 key candidate genes, Figure S4: Enrichment analysis of Gene Ontology of 831 key candidate genes, Table S4: Genotype and allele frequencies of these six SNPs, Table S5: The association between SNPs and the gene expression level, Table S6: The association between SNPs and the gene expression level.

Author Contributions: Conceptualization, L.L., J.W. and K.Z.; methodology, K.Z., J.W., F.D. and R.S.; software, K.Z. and J.W.; validation, K.Z.; investigation, K.Z. and J.W.; resources, L.L.; data curation, K.Z. and J.W.; writing-original draft preparation, K.Z. and J.W.; writing-review and editing, K.Z., J.W., L.L., F.D., R.S., W.W. and G.Z.; visualization, K.Z.; project administration, L.L. and W.W.; funding acquisition, L.L. All authors have read and agreed to the published version of the manuscript.

Funding: This research was funded by the National Key R\&D Program of China (No. 2018YFD0900304), the Strategic Priority Research Program of the Chinese Academy of Sciences (Grant No. XDA23050402), the Key Deployment Project of the Centre for Ocean Mega-Research of Science, Chinese Academy of Sciences (COMS2019Q06), the Distinguished Young Scientists Research Fund of the Key Laboratory of Experimental Marine Biology, Chinese Academy of Sciences (No. KLEMB-DYS04), Blue Life Breakthrough Program of LMBB of Qingdao National Laboratory for Marine Science and Technology (MS2018NO02), and the Technology and the Modern Agroindustry Technology Research System (No. CARS-49).

Institutional Review Board Statement: Not applicable. 
Informed Consent Statement: Not applicable.

Data Availability Statement: Not applicable.

Acknowledgments: We extend our sincerest gratitude to all contributed to the work.

Conflicts of Interest: We declare we have no competing interests.

\section{References}

1. Cheng, L.; Abraham, J.; Hausfather, Z.; Trenberth, K.E. How fast are the oceans warming? Science 2019, 363, 128-129. [CrossRef]

2. Schulte, P.M. The effects of temperature on aerobic metabolism: Towards a mechanistic understanding of the responses of ectotherms to a changing environment. J. Exp. Biol. 2015, 218, 1856-1866. [CrossRef]

3. Tang, H.Y.; Smith-Caldas, M.S.; Driscoll, M.V.; Salhadar, S.; Shingleton, A.W. FOXO regulates organ-specific pheno-typic plasticity in Drosophila. PLoS Genet. 2011, 7, e1002373. [CrossRef]

4. Chevin, L.-M.; Lande, R.; Mace, G. Adaptation, Plasticity, and Extinction in a Changing Environment: Towards a Predictive Theory. PLoS Biol. 2010, 8, e1000357. [CrossRef]

5. Gienapp, P.; Teplitsky, C.; Alho, J.S.; Mills, J.A.; Merilä, J. Climate change and evolution: Disentangling environmental and genetic responses. Mol. Ecol. 2008, 17, 167-178. [CrossRef] [PubMed]

6. Kelly, M. Adaptation to climate change through genetic accommodation and assimilation of plastic phenotypes. Philos. Trans. R. Soc. B Biol. Sci. 2019, 374, 20180176. [CrossRef]

7. Whitman, D.; Ananthakrishnan, T. What is Phenotypic Plasticity and Why is it Important? Phenotypic Plast. Insects Mech. Conseq. 2009, 1-63. [CrossRef]

8. Ghaffari, H.; Wang, W.; Li, A.; Zhang, G.; Li, L. Thermotolerance Divergence Revealed by the Physiological and Mo-lecular Responses in Two Oyster Subspecies of Crassostrea gigas in China. Front. Physiol. 2019, 10, 1137. [CrossRef]

9. Li, A.; Li, L.; Song, K.; Wang, W.; Zhang, G. Temperature, energy metabolism, and adaptive divergence in two oyster subspecies. Ecol. Evol. 2017, 7, 6151-6162. [CrossRef]

10. Li, A.; Li, L.; Wang, W.; Zhang, G. Evolutionary trade-offs between baseline and plastic gene expression in two con-generic oyster species. Biol. Lett. 2019, 15, 20190202. [CrossRef]

11. Albert, F.; Kruglyak, L. The role of regulatory variation in complex traits and disease. Nat. Rev. Genet. 2015, 16, 197-212. [CrossRef]

12. Claussnitzer, M.; Dankel, S.N.; Kim, K.-H.; Quon, G.; Meuleman, W.; Haugen, C.; Glunk, V.; Sousa, I.S.; Beaudry, J.L.; Puviindran, V.; et al. FTO Obesity Variant Circuitry and Adipocyte Browning in Humans. N. Engl. J. Med. 2015, 373, 895-907. [CrossRef]

13. Cubillos, A.F.; Coustham, V.; Loudet, O. Lessons from eQTL mapping studies: Non-coding regions and their role behind natural phenotypic variation in plants. Curr. Opin. Plant Biol. 2012, 15, 192-198. [CrossRef]

14. Musunuru, K.; Strong, A.; Frank-Kamenetsky, M.; Lee, N.E.; Ahfeldt, T.; Sachs, K.V.; Li, X.; Li, H.; Kuperwasser, N.; Ruda, V.M.; et al. From noncoding variant to phenotype via SORT1 at the 1 p13 cholesterol locus. Nature 2010, 466, 714-719. [CrossRef] [PubMed]

15. Sokolova, I.M.; Frederich, M.; Bagwe, R.; Lannig, G.; Sukhotin, A. Energy homeostasis as an integrative tool for assessing limits of environmental stress tolerance in aquatic invertebrates. Mar. Environ. Res. 2012, 79, 1-15. [CrossRef] [PubMed]

16. Chen, Y.; Liu, E.; Li, C.; Pan, C.; Zhao, X.; Wang, Y.; Ling, Q. Effects of heat stress on histopathology, antioxidant enzymes, and transcriptomic profiles in gills of pikeperch Sander lucioperca. Aquaculture 2021, 534, 736277. [CrossRef]

17. Li, P.; Liu, Q.; Li, J.; Wang, F.; Wen, S.; Li, N. Transcriptomic responses to heat stress in gill and liver of endangered Brachymystax lenok tsinlingensis. Comp. Biochem. Physiol. Part D Genom. Proteom. 2021, 38, 100791. [CrossRef]

18. Cottin, D.; Shillito, B.; Chertemps, T.; Tanguy, A.; Léger, N.; Ravaux, J. Identification of differentially expressed genes in the hydrothermal vent shrimp Rimicaris exoculata exposed to heat stress. Mar. Genom. 2010, 3, 71-78. [CrossRef]

19. Rahi, M.L.; Mahmud, S.; Dilruba, K.J.; Sabbir, W.; Aziz, D.; Hurwood, D.A. Temperature induced changes in physio-logical traits and expression of selected candidate genes in black tiger shrimp (Penaeus monodon) larvae. Aquac. Rep. 2021, 19. [CrossRef]

20. Hamdoun, A.; Cheney, D.P.; Cherr, G.N. Phenotypic Plasticity of HSP70 and HSP70 Gene Expression in the Pacific Oyster (Crassostrea gigas): Implications for Thermal Limits and Induction of Thermal Tolerance. Biol. Bull. 2003, 205, 160-169. [CrossRef] [PubMed]

21. Jones, H.R.; Johnson, K.; Kelly, M.W. Synergistic Effects of Temperature and Salinity on the Gene Expression and Physiology of Crassostrea virginica. Integr. Comp. Biol. 2019, 59, 306-319. [CrossRef]

22. Li, S.; Liu, C.; Huang, J.; Liu, Y.; Zhang, S.; Zheng, G.; Xie, L.; Zhang, R. Transcriptome and biomineralization responses of the pearl oyster Pinctada fucata to elevated CO2 and temperature. Sci. Rep. 2016, 6, 18943. [CrossRef]

23. Liu, W.; Huang, X.; Lin, J.; He, M. Seawater Acidification and Elevated Temperature Affect Gene Expression Patterns of the Pearl Oyster Pinctada fucata. PLoS ONE 2012, 7, e33679. [CrossRef]

24. Li, L.; Li, A.; Song, K.; Meng, J.; Guo, X.; Li, S.; Li, C.; De Wit, P.; Que, H.; Wu, F.; et al. Divergence and plasticity shape adaptive potential of the Pacific oyster. Nat. Ecol. Evol. 2018, 2, 1751-1760. [CrossRef]

25. Zhang, G.; Fang, X.; Guo, X.; Li, L.; Luo, R.; Xu, F.; Yang, P.; Zhang, L.; Wang, X.; Qi, H.; et al. The oyster genome reveals stress adaptation and complexity of shell formation. Nat. Cell Biol. 2012, 490, 49-54. [CrossRef] 
26. Kita, R.; Venkataram, S.; Zhou, Y.; Fraser, H.B. High-resolution mapping of cis-regulatory variation in budding yeast. Proc. Natl. Acad. Sci. USA 2017, 114, E10736-E10744. [CrossRef] [PubMed]

27. Druka, A.; Potokina, E.; Luo, Z.; Jiang, N.; Chen, X.; Kearsey, M.; Waugh, R. Expression quantitative trait loci analysis in plants. Plant Biotechnol. J. 2010, 8, 10-27. [CrossRef]

28. Rockman, M.V.; Kruglyak, L. Genetics of global gene expression. Nat. Rev. Genet. 2006, 7, 862-872. [CrossRef] [PubMed]

29. Holloway, B.; Luck, S.; Beatty, M.; Rafalski, J.-A.; Li, B. Genome-wide expression quantitative trait loci (eQTL) analysis in maize. BMC Genom. 2011, 12, 336. [CrossRef] [PubMed]

30. Benton, M.C.; Lea, R.A.; Macartney-Coxson, D.; Carless, M.A.; Göring, H.H.; Bellis, C.; Hanna, M.; Eccles, D.; Chambers, G.K.; Curran, J.E.; et al. Mapping eQTLs in the Norfolk Island Genetic Isolate Identifies Candidate Genes for CVD Risk Traits. Am. J. Hum. Genet. 2013, 93, 1087-1099. [CrossRef]

31. Cesar, A.S.M.; Regitano, L.C.A.; Reecy, J.M.; Poleti, M.D.; Oliveira, P.S.N.; de Oliveira, G.B.; Moreira, G.C.M.; Mudadu, M.A.; Tizioto, P.C.; Koltes, J.E.; et al. Identification of putative regulatory regions and transcription factors associated with in-tramuscular fat content traits. BMC Genom. 2018, 19, 499. [CrossRef]

32. Orozco, L.D.; Chen, H.-H.; Cox, C.; Katschke, K.J.; Arceo, R.; Espiritu, C.; Caplazi, P.; Nghiem, S.S.; Chen, Y.-J.; Modrusan, Z.; et al. Integration of eQTL and a Single-Cell Atlas in the Human Eye Identifies Causal Genes for Age-Related Macular Degeneration. Cell Rep. 2020, 30, 1246-1259.e6. [CrossRef]

33. Ramasamy, A.; UK Brain Expression Consortium; Trabzuni, D.; Guelfi, S.; Varghese, V.; Smith, C.; Walker, R.; De, T.; Coin, L.; De Silva, R.; et al. Genetic variability in the regulation of gene expression in ten regions of the human brain. Nat. Neurosci. 2014, 17, 1418-1428. [CrossRef]

34. Steige, K.A.; Reimegard, J.; Koenig, D.; Scofield, D.G.; Slotte, T. Cis-Regulatory Changes Associated with a Recent Mating System Shift and Floral Adaptation in Capsella. Mol. Biol. Evol. 2015, 32, 2501-2514. [CrossRef]

35. Ting, N.C.; Jansen, J.; Nagappan, J.; Ishak, Z.; Chin, C.W.; Tan, S.G.; Cheah, S.C.; Singh, R. Identification of QTLs associated with callogenesis and embryogenesis in oil palm using genetic linkage maps improved with SSR markers. PLoS ONE 2013, 8, e53076. [CrossRef]

36. Pritchard, V.L.; Viitaniemi, H.M.; McCairns, R.J.S.; Merilä, J.; Nikinmaa, M.; Primmer, C.R.; Leder, E.H. Regulatory Architecture of Gene Expression Variation in the Threespine Stickleback Gasterosteus aculeatus. Genes Genomes Genet. 2017, 7, 165-178. [CrossRef]

37. Bouchet, V.M.; Debenay, J.-P.; Sauriau, P.-G.; Radford-Knoery, J.; Soletchnik, P. Effects of short-term environmental disturbances on living benthic foraminifera during the Pacific oyster summer mortality in the Marennes-Oléron Bay (France). Mar. Environ. Res. 2007, 64, 358-383. [CrossRef] [PubMed]

38. Cotter, E.; Malham, S.K.; O’Keeffe, S.; Lynch, S.A.; Latchford, J.W.; King, J.W.; Beaumont, A.R.; Culloty, S.C. Summer mortality of the Pacific oyster, Crassostrea gigas, in the Irish Sea: The influence of growth, biochemistry and gametogenesis. Aquaculture 2010, 303, 8-21. [CrossRef]

39. Wendling, C.C.; Wegner, K.M. Relative contribution of reproductive investment, thermal stress and Vibrio infection to summer mortality phenomena in Pacific oysters. Aquaculture 2013, 412-413, 88-96. [CrossRef]

40. Samain, J.; Dégremont, L.; Soletchnik, P.; Haure, J.; Bédier, E.; Ropert, M.; Moal, J.; Huvet, A.; Bacca, H.; Van Wormhoudt, A.; et al. Genetically based resistance to summer mortality in the Pacific oyster (Crassostrea gigas) and its relationship with physiological, immunological characteristics and infection processes. Aquaculture 2007, 268, 227-243. [CrossRef]

41. Ren, J.; Liu, X.; Jiang, F.; Guo, X.; Liu, B. Unusual conservation of mitochondrial gene order in Crassostrea oysters: Evidence for recent speciation in Asia. BMC Evol. Biol. 2010, 10, 394. [CrossRef]

42. Wang, J.; Li, L.; Zhang, G. A High-Density SNP Genetic Linkage Map and QTL Analysis of Growth-Related Traits in a Hybrid Family of Oysters (Crassostrea gigas $\times$ Crassostrea angulata) Using Genotyping-by-Sequencing. G3 2016, 6, 1417-1426. [CrossRef]

43. Livak, K.J.; Schmittgen, T.D. Analysis of relative gene expression data using real-time quantitative PCR and the 2(-Delta Delta C(T)) Method. Methods 2001, 25, 402-408. [CrossRef] [PubMed]

44. Van Oojien, J.W. Software for the Mapping of Quantitative Trait Loci in Experimental Populations of Diploid Species. Biology 2009, 18-24.

45. Young, M.D.; Wakefield, M.J.; Smyth, G.K.; Oshlack, A. Gene ontology analysis for RNA-seq: Accounting for selection bias. Genome Biol. 2010, 11, R14. [CrossRef]

46. Kanehisa, M.; Araki, M.; Goto, S.; Hattori, M.; Hirakawa, M.; Itoh, M.; Katayama, T.; Kawashima, S.; Okuda, S.; Tokimatsu, T.; et al. KEGG for linking genomes to life and the environment. Nucleic Acids Res. 2007, 36, D480-D484. [CrossRef] [PubMed]

47. Li, Z.; Zhang, Z.; He, Z.; Tang, W.; Li, T.; Zeng, Z.; He, L.; Shi, Y. A partition-ligation-combination-subdivision EM algorithm for haplotype inference with multiallelic markers: Update of the SHEsis (http:/ / analysis.bio-x.cn). Cell Res. 2009, 19, 519-523. [CrossRef]

48. Shen, J.; Li, Z.; Chen, J.; Song, Z.; Zhou, Z.; Shi, Y. SHEsisPlus, a toolset for genetic studies on polyploid species. Sci. Rep. 2016, 6, 24095. [CrossRef]

49. Yong, Y.; He, L. SHEsis, a powerful software platform for analyses of linkage disequilibrium, haplotype construction, and genetic association at polymorphism loci. Cell Res. 2005, 15, 97-98. [CrossRef] 
50. Sołtys-Kalina, D.; Szajko, K.; Stefańczyk, E.; Smyda-Dajmund, P.; Śliwka, J.; Marczewski, W. eQTL mapping of the 12S globulin cruciferin gene PGCRURSE5 as a novel candidate associated with starch content in potato tubers. Sci. Rep. 2020, $10,17168$. [CrossRef]

51. Criado-Mesas, L.; Ballester, M.; Crespo-Piazuelo, D.; Castelló, A.; Fernández, A.I.; Folch, J.M. Identification of eQTLs associated with lipid metabolism in Longissimus dorsi muscle of pigs with different genetic backgrounds. Sci. Rep. 2020, 10, 9845. [CrossRef]

52. DeCook, R.; Lall, S.; Nettleton, D.; Howell, S.H. Genetic Regulation of Gene Expression During Shoot Development in Arabidopsis. Genet. 2006, 172, 1155-1164. [CrossRef]

53. Liu, H.; Luo, X.; Niu, L.; Xiao, Y.; Chen, L.; Liu, J.; Wang, X.; Jin, M.; Li, W.; Zhang, Q.; et al. Distant eQTLs and Non-coding Sequences Play Critical Roles in Regulating Gene Expression and Quantitative Trait Variation in Maize. Mol. Plant 2017, 10, 414-426. [CrossRef] [PubMed]

54. Grishkevich, V.; Yanai, I. The genomic determinants of genotype x environment interactions in gene expression. Trends Genet. 2013, 29, 479-487. [CrossRef] [PubMed]

55. Landry, C.R.; Wittkopp, P.J.; Taubes, C.H.; Ranz, J.M.; Clark, A.; Hartl, D.L. Compensatory cis-trans Evolution and the Dysregulation of Gene Expression in Interspecific Hybrids of Drosophila. Genetics 2005, 171, 1813-1822. [CrossRef] [PubMed]

56. Schaefke, B.; Emerson, J.; Wang, T.-Y.; Lu, M.-Y.J.; Hsieh, L.-C.; Li, W.-H. Inheritance of Gene Expression Level and Selective Constraints on Trans- and Cis-Regulatory Changes in Yeast. Mol. Biol. Evol. 2013, 30, 2121-2133. [CrossRef] [PubMed]

57. Guerrero, R.F.; Posto, A.L.; Moyle, L.C.; Hahn, M.W. Genome-wide patterns of regulatory divergence revealed by introgression lines. Evolution 2016, 70, 696-706. [CrossRef]

58. Meiklejohn, C.D.; Coolon, J.D.; Hartl, D.L.; Wittkopp, P.J. The roles of cis- and trans-regulation in the evolution of regulatory incompatibilities and sexually dimorphic gene expression. Genome Res. 2013, 24, 84-95. [CrossRef]

59. Shi, X.; Ng, D.W.-K.; Zhang, C.; Comai, L.; Ye, W.; Chen, Z.J. Cis- and trans-regulatory divergence between progenitor species determines gene-expression novelty in Arabidopsis allopolyploids. Nat. Commun. 2012, 3, 950. [CrossRef]

60. Xiong, J. Atg7 in development and disease: Panacea or Pandora's Box? Protein Cell 2015, 6, 722-734. [CrossRef]

61. Phillips, J.J.; Gong, H.; Chen, K.; Joseph, N.M.; Van Ziffle, J.; Jin, L.-W.; Bastian, B.; Bollen, A.W.; Perry, A.; Nicolaides, T.; et al. Activating NRF1-BRAF and ATG7-RAF1 fusions in anaplastic pleomorphic xanthoastrocytoma without BRAF p.V600E mutation. Acta Neuropathol. 2016, 132, 757-760. [CrossRef]

62. Li, S.; Hua, W.; Wang, K.; Gao, Y.; Chen, S.; Liu, W.; Song, Y.; Wu, X.; Tu, J.; Kang, L.; et al. Autophagy attenuates compressioninduced apoptosis of human nucleus pulposus cells via MEK/ERK/NRF1/Atg7 signaling pathways during in-tervertebral disc degeneration. Exp. Cell Res. 2018, 370, 87-97. [CrossRef] [PubMed]

63. Bukau, B.; Horwich, A.L. The Hsp70 and Hsp60 Chaperone Machines. Cell 1998, 92, 351-366. [CrossRef]

64. Kampinga, H.H.; Craig, E.A. The HSP70 chaperone machinery: J proteins as drivers of functional specificity. Nat. Rev. Mol. Cell Biol. 2010, 11, 579-592. [CrossRef] [PubMed]

65. Mayer, M.P.; Bukau, B. Hsp70 chaperones: Cellular functions and molecular mechanism. Cell. Mol. Life Sci. 2005, 62, 670-684. [CrossRef]

66. Del Campo, E.M.; Casano, L.M.; Barreno, E. Evolutionary implications of intron-exon distribution and the properties and sequences of the RPL10A gene in eukaryotes. Mol. Phylogenet. Evol. 2013, 66, 857-867. [CrossRef]

67. Wonglapsuwan, M.; Miyazaki, T.; Loongyai, W.; Chotigeat, W. Characterization and Biological Activity of the Ribosomal Protein L10a of the White Shrimp: Fenneropenaeus merguiensis De Man during Vitellogenesis. Mar. Biotechnol. 2009, 12, 230-240. [CrossRef] 